\title{
Heat Transfer Analysis in a Single Spool Gas Turbine by Using Calculated-Estimated Coefficients with the Finite Element Method
}

\author{
Geraldo Creci ${ }^{1, *(\mathbb{D}}$, Márcio Teixeira de Mendoça ${ }^{2}$, João Carlos Menezes ${ }^{3}$ \\ and João Roberto Barbosa ${ }^{3}$ \\ 1 Instituto Federal de Educação, Ciência e Tecnologia de São Paulo (IFSP-BRA), Av. Major Fernando Valle, \\ 2013, Bragança Paulista, SP 12903-000, Brazil \\ 2 Instituto de Aeronáutica e Espaço (IAE), Pr. Marechal Eduardo Gomes, 50, \\ São José dos Campos, SP 12228-904, Brazil; marciomtm@fab.mil.br \\ 3 Instituto Tecnológico de Aeronáutica (ITA), Pr. Marechal Eduardo Gomes, 50 \\ São José dos Campos, SP 12228-900, Brazil; menezes@ita.br (J.C.M.); barbosa@ita.br (J.R.B.) \\ * Correspondence: gcreci@ifsp.edu.br; Tel.: +55-11-98100-2656
}

Received: 2 November 2020; Accepted: 19 November 2020; Published: 24 November 2020

check for updates

Featured Application: At the end of the development program, the gas turbine should be able to drive an unmanned aerial vehicle weighing a maximum of $1200 \mathrm{~kg}$ and generate $1.0 \mathrm{MW} / \mathrm{h}$ of electricity. The application in the civilian market of electricity generation aims to increase the financial possibilities of success of the program, where biofuel (ethanol), derived from sugar cane, will be one of the main fuels used for motor combustion.

\begin{abstract}
In this paper, a calculation procedure is presented to estimate the heat transfer coefficients of a single spool gas turbine designed to generate $5 \mathrm{kN}$ of thrust. These heat transfer coefficients are the boundary conditions which govern the heat interaction between the solid parts and the working fluid in the gas turbine. However, the calculation of these heat transfer coefficients is not a trivial task, since it depends on complex fluid flow conditions. Empirical correlations and assumptions have been used to find convective heat transfer coefficients over most components, including stator vanes, rotor blades, disc faces, and disc platforms. After defining the heat transfer coefficients, the finite element method was used to determine the temperature distribution in one eighth section of the gas turbine making use of the problem cyclic symmetry. Both static and rotating assemblies have been modeled. The results allowed the prediction of the thermal expansion behavior of the whole single spool gas turbine with special attention to the safety margin of clearances. Furthermore, having the temperature distribution defined, it is possible to calculate the thermal stresses in any mechanical component. Additionally, it is possible to specify suitable metallic alloys for achieving appropriate performance in every case. The structural integrity of all components was then assured with the temperature distribution and thermal expansion behavior under knowledge. Thus, the mechanical drawings could be released to manufacturing.
\end{abstract}

Keywords: aeroengine; temperature distribution; dilatation; convective coefficients; numerical methods; structural integrity

\section{Introduction}

During the design process, the computational simulation phase is extremely important, so that no faults occur during operation, thus avoiding serious losses and accidents. The aeronautical gas turbine studied in this work has already been designed and is under development. With an approximate 
weight of $650 \mathrm{~N}$, a maximum diameter of $0.350 \mathrm{~m}$, and a maximum length of $1.50 \mathrm{~m}$, that aeronautical gas turbine is capable of producing $5 \mathrm{kN}$ of thrust at the rotational speed of $28,150 \mathrm{rpm}$ [1-4]. Figure 1a,b illustrate the aeronautical gas turbine studied in this work on the test rig. It is composed of an air inlet duct, a five-stage axial compressor, a direct-flow annular combustion chamber, a single stage turbine disc, and an exhaustion nozzle, in a single shaft configuration. Figure 2a,b show the compressor and turbine discs and Figure 2c shows the whole rotor assembly without bearings.
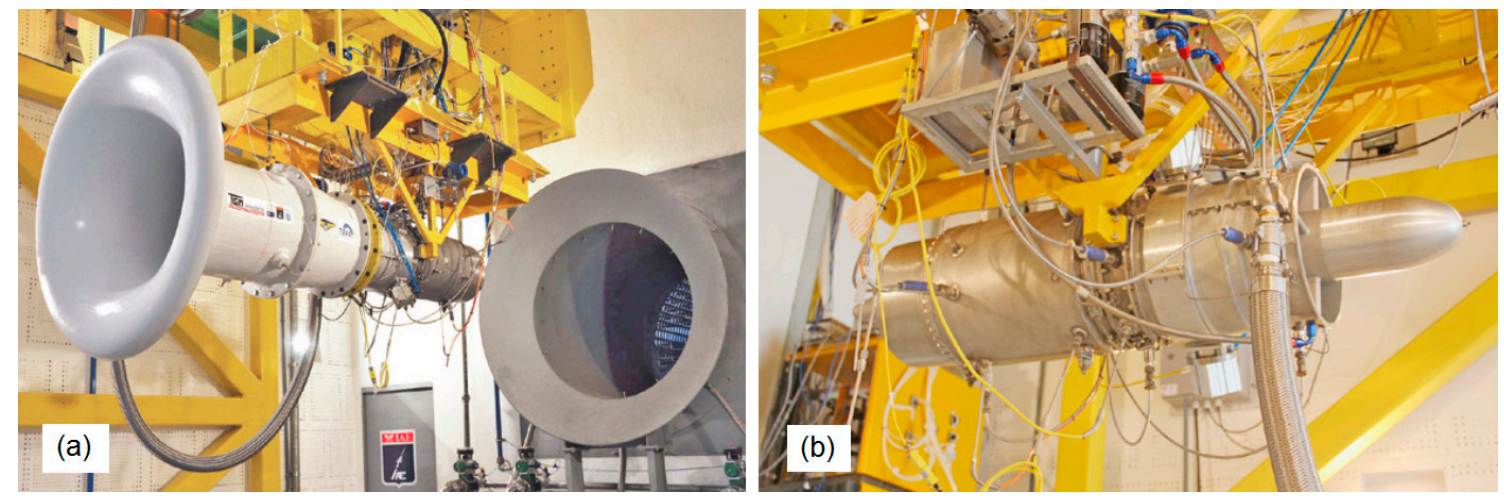

Figure 1. Illustration of the aeronautical gas turbine studied in this work on test rig: (a) Perspective view including inlet and exhaustion ducts; (b) Side view.
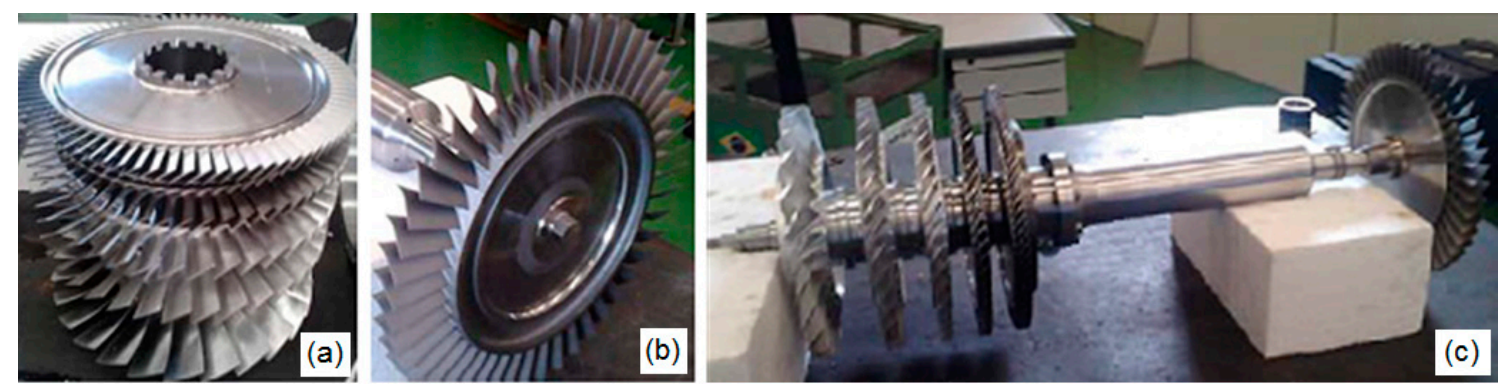

Figure 2. Rotating assembly of the aeronautical gas turbine with its compressor and turbine discs:

(a) Compressor discs; (b) Turbine disc; (c) All rotating assembly.

Gas turbines operate under rigorous conditions of temperature and stress. High temperatures are necessary to increase thermal efficiency and reduce fuel consumption. However, high temperatures can compromise structural integrity of mechanical components by reducing the yield strength in metallic alloys and/or favoring creep. That is why it is important to calculate the temperature distribution over the main static and rotating components of a gas turbine. The determination of the temperature distribution over the gas turbine components makes it possible to select appropriate metallic alloys to withstand the rigorous operating conditions. However, in some cases there is no appropriate metallic alloy able to meet the design requirements, and a redesign process must be conducted. In order to overcome the material barrier, extensive research and development in new metallic alloys and other materials has been done. The main objective is to be able to use higher and higher temperatures at the turbine disc entry to improve overall efficiency.

Compressor and turbine discs are critical components that should be carefully analyzed. These components are under high thermal stresses and high centrifugal loads. In spite of the fact that higher temperatures are found on turbine discs, compressor discs can also be potentially dangerous. This happens because aluminum alloys, which are usually used in compressor discs, present a strong reduction in their mechanical properties with temperature increase. In high performance compressors, the last rotor stages are made of high temperature alloys in order to withstand the high thermal and structural effects. In turbine discs, the use of Inconel alloys is a choice in the great majority of cases, since Inconel alloys present superior mechanical properties at elevated temperatures. 
The heat transfer analysis presented in this paper simulates the temperature distribution over the main gas turbine components. It also provides the thermal expansion behavior of the static and rotating assemblies. With the increase in temperature in the aeronautical gas turbine there will be a proportional increase in the structural demanding for both rotating and static assemblies in terms of amplitudes of vibration. Furthermore, when considering higher temperatures, damage to the main parts of the aeronautical gas turbine is accelerated as a result of more severe fluid-structure interaction. Thus, structural analyses can be performed taking into account the thermal effects predicted, which makes it possible to assure that problems generated by high temperatures like creep, thermal stresses, reduction in mechanical strength or insufficient clearances do not cause structural collapse or malfunctioning over the studied gas turbine.

\section{Literature Review}

Mazur et al. [5] analyzed the blade failure of the first 70 MW gas turbine made of Inconel 738LC. There was degradation of the coating due to the operation at high temperature, leading to crack initiation by fatigue/creep mechanisms. Sadowski and Golewski [6] studied, by the finite element method, the Inconel 713 alloy for the problem of heat transfer in gas turbines. Kim et al. [7] investigated heat transfer and thermal stresses in a gas turbine blade with 10 internal cooling passages. Numerical three-dimensional (3D) simulations were performed using the CFX and Ansys software to calculate the temperature distributions and heat transfer coefficients. Hesham et al. [8] investigated the three-dimensional heat transfer characteristics of a gas turbine blade. The numerical results presented good agreement with experimental measurements. Chen-Zhao et al. [9] studied the fluid flow and heat transfer characteristics in the pipe cable with alternating current by using commercial code COMSOL Multiphysics based on the finite element method. Bade et al. [10] used the MATLAB/Simulink numerical model of a single cylinder, mechanical spring assisted, two-stroke natural gas fueled, spark-ignited oscillating linear engine alternator to investigate the effect of combustion and heat transfer characteristics on translator dynamics and performance. Dou, Jiang, and Zhang [11] investigated the thermal flow and heat transfer by natural convection in a cavity fixed with a fin array. The computational domain consisted of both solid (copper) and fluid (air) areas. The finite volume method was used to simulate the steady flow in the domain. Jedsadaratanachai and Boonloi [12] investigated numerically the heat transfer, pressure loss, and thermal enhancement factor in the circular tube heat exchanger inserted with V-orifices. Badreddine et al. [13] focused on the development and application of a new finite volume immersed boundary method to simulate three-dimensional fluid flows and heat transfer around complex geometries that also exist in gas turbines. Devaraj, Muthuswamy, and Kandasamy [14] studied numerically natural convection heat transfer in a two-dimensional square enclosure at various angles of inclination. The calculated correlation coefficients for the entire range of Rayleigh numbers were in good agreement with other published numerical results, thus, attesting that the achieved results were satisfactory. Several areas were, thus, numerically studied; the results were compared to empirical data showing agreement and with engineering application opportunity. This encouraged the study described in this paper.

\section{Convective Heat Transfer Coefficients}

In this section, the correlations used to estimate the convective heat transfer coefficients are presented. The coefficients are determined largely by mathematical relations, but also by numerical approximations using reasonable concepts within maximum and minimum limits based on common sense according to the current application and similar case studies. The heat flux from hot gases to metallic surfaces can be estimated using Newton's convective heat transfer law

$$
q=h\left(T_{g}-T_{w}\right)
$$


where $q$ is the heat flux, $h$ is the convective heat transfer coefficient, $T_{g}$ is the reference gas temperature and $T_{w}$ is the wall temperature. For compressible flow the reference temperature is the adiabatic wall temperature $T_{a w}$. The adiabatic wall temperature, defined as

$$
T_{a w}=T_{s}+r\left(T_{T}-T_{s}\right),
$$

takes into account energy dissipation due to viscous heating. $T_{S}$ is the static temperature, $T_{T}$ is the total stagnation temperature and $r$ is the recovery factor. The recovery factor takes into account the diffusivity of heat and momentum. If heat diffuses faster than momentum, the thermal boundary layer is thinner than the momentum boundary layer. In this case, a higher heat transfer rate is expected. The Prandtl number is used to compare the diffusivity of heat and momentum, such that the recovery factor is defined as

$$
r=\operatorname{Pr}^{1 / 2} \text { (for laminar flow) and } r=\operatorname{Pr}^{1 / 3} \text { (for turbulent flow). }
$$

For $P r=0.7, r$ is equal to 0.83 and 0.88 respectively. In this work an average value $P r=0.85$ will be assumed, regardless of the flow regime. The distribution of the heat transfer coefficient over the surface depends on the flow conditions, gas velocity and temperature distributions. Given the gas temperature distribution, the heat flux q can be computed by Fourier's Law as a function of the thermal conductivity of the gas $k_{g}$ and the temperature gradient $(d T / d y)_{p^{\prime}}$

$$
q=-k_{g}\left(\frac{d T}{d y}\right)_{p}
$$

The heat transfer coefficient can be expressed in nondimensional form, which results in the Nusselt number $\mathrm{Nu}$ which is defined by

$$
N u=\frac{h x}{k_{g}} .
$$

The solution of the fluid mechanics governing equations, even when the boundary layer approximation is used, is very complex for compressible flows with temperature dependent fluid properties. In a preliminary study, the heat transfer coefficient may be estimated by simplified analytical and experimental correlations. The heat transfer models presented in this paper are based on these correlations for a first order approximation. In the following sections, correlations for heat transfer coefficients are presented for the flow over stator vanes and disc blades, compressor and turbine disc faces, and compressor and turbine platforms (inner wall) and casing (outer wall).

\subsection{Stator Vanes and Disc Blades}

In a first order approximation, the boundary layer over a stator vane or disc blade may be represented by the boundary layer over a flat plane. For a laminar flow the velocity and temperature distributions are given by the Blasius solution [15]. In this case the convective heat transfer correlation is

$$
h(x)=0.332 \frac{k_{g}}{x} \operatorname{Re}_{x}^{1 / 2} \operatorname{Pr}^{1 / 3},
$$

where $x$ is the longitudinal distance from the leading edge, $k_{g}$ is the gas thermal conductivity, Re and Pr are the nondimensional Reynolds and Prandtl numbers calculated by

$$
R e=\frac{\rho_{g} u_{g} x}{\mu_{g}} \text { and } \operatorname{Pr}=\frac{\mu_{g} C p}{k_{g}} .
$$


where $\rho_{g}$ is the gas density, $u_{g}$ is the freestream gas velocity at $x, \mu$ is the gas dynamic viscosity, and $C p$ is the gas specific heat at constant pressure. For turbulent flow the heat transfer coefficient is given by [16].

$$
h(x)=0.0296 \frac{k_{g}}{D}\left(\operatorname{Re}_{x}^{0.8} \operatorname{Pr}^{1 / 3}\right) .
$$

At the leading edge, the heat transfer coefficient can be estimated based on the flow over a cylindrical surface

$$
h_{a}=a\left[1.14 \frac{k_{g}}{D}\left(\operatorname{Re}_{D}\right)^{1 / 2} \operatorname{Pr}^{0.4}\right]
$$

where $a$ is a turbulence enhancement factor, $D$ is the leading edge diameter and $R e_{D}$ is the Reynolds number based on the leading edge diameter and the approaching freestream velocity. The average heat transfer coefficient over the cylindrical surface at the leading edge is given by

$$
h_{a v}=0.7 h_{a} .
$$

The gas properties are computed as a function of temperature. In the present model the Prandtl number is assumed to be constant and equal to $P r=0.7$. The viscosity varies with temperature according to the power law [17],

$$
\mu_{g}=\mu_{0}\left(\frac{T_{g}}{T_{0}}\right)^{0.67}
$$

where the reference viscosity of air is $\mu_{0}=1.5 \times 10^{-5}$ at the reference temperature of $T_{0}=273(\mathrm{~K})$. For combustion gases the reference viscosity is $\mu_{g}=4.23 \times 10^{-5}(\mathrm{~kg} /(\mathrm{m} . \mathrm{s}))$ at the reference temperature of $T_{0}=1100(\mathrm{~K})$. The conductivity is computed from the definition of Prandtl number and the density is calculated by the perfect gas law

$$
k_{g}=\frac{\mu_{g} C p}{P r} \text { and } \rho_{g}=\frac{P}{R T_{g}} .
$$

Equations (6), (8), and (10) are used to estimate the heat transfer coefficient distribution over the turbine blades and vanes. The same correlations apply to compressor blades and diffuser vanes. At the leading edge, the flow is always laminar and Equations (6) and (10) are used. Close to the trailing edge, the flow is usually turbulent and Equation (8) should be used. In gas turbine blades and vanes, the laminar and turbulent regions are separated by a transition zone that has a significant length compared to the chord. On the suction surface for both blades and vanes, there is a strong adverse pressure gradient, which hastens the transition to turbulence. In the present suction surface model, it is considered that the transition region starts at $10 \%$ of the chord, considering the leading edge as the starting point. It is also considered that the transition region ends at $40 \%$ of the chord. From this point on, the flow is assumed to be turbulent. On the pressure surface, the strong favorable pressure gradient close to the leading edge forces the flow to remain laminar. On the other hand, the freestream turbulence levels from the combustion chamber and the strong concave surface curvature try to transition the flow to a turbulent regime. These opposing effects result in a long transition region over the stator vanes. The assumed model in this work considers that on the pressure surface of the stator vanes, the transition starts at $20 \%$ of the chord length, starting from the leading edge. The flow is considered fully turbulent at $90 \%$ of the chord length. On rotor blades, the flow is considered fully turbulent at $30 \%$ of the chord. On the compressor rotor blades and diffuser vanes, the flow is considered fully turbulent from the leading edge due to the strong adverse pressure gradient throughout. These are typical values for gas turbine blades and vanes. 
The heat transfer coefficient on the transition region is assumed as an average between the laminar regime, $l$, and the turbulent regime, $t$, weighted by the stream wise position between transition start $(t s)$ and transition end (te)

$$
h(x)=h_{l}\left(1-\frac{x_{i}-x_{t s}}{x_{t e}-x_{t s}}\right)+h_{t}\left(\frac{x_{i}-x_{t s}}{x_{t e}-x_{t s}}\right) .
$$

The distribution of convective heat transfer along the vanes or blades is used to compute an integral average heat transfer coefficient at three different radial positions, base, mid span, and tip. Given that the leading edge diameter is less than $1 \mathrm{~mm}$, the coefficient $h_{l e}$ would be an unrealistically high value. Therefore, it will not be used to evaluate the average value. The proposed model for the leading edge is only valid for thicker blades of cooled turbine blades.

\subsection{Compressor and Turbine Discs}

This section presents heat transfer correlations for spinning discs when they are cooled by an outward flow of cooling air and when the discs are cooled by an impingement jet at the disc rim, which is of much use. It also presents the disc heat transfer correlation to calculate the disc heat transfer coefficient without cooling flow.

\subsubsection{Convective Cooling}

The Nusselt number $N u=h r_{o} / k$ on a spinning disc may be correlated according to Evans [18] as

$$
N u=0.0346\left(\operatorname{Re}_{r_{o}}\right)^{0.8}\left(k_{v}\right)^{-0.1}\left(\frac{r_{o}}{r_{c}}\right)^{-0.3}\left(\frac{z}{r_{o}}\right)^{0.06} \operatorname{Pr}^{0.6},
$$

where $r_{o}$ is the disc external radius and $r_{c}$ is the radial position where the cooling flow is introduced.

$$
k_{v}=\frac{R e_{r_{o}}}{\left(r_{o} / r_{c}\right)^{2} R e_{m}}
$$

The mass flow Reynolds number $R e_{m}$ is defined as a function of the coolant volumetric flow rate $Q_{p}$, with $z$ being the disc clearance at the rim and $v$ being the kinematic viscosity. The rotational Reynolds number $R e_{r_{o}}$ is defined as a function of the angular velocity $w$

$$
R e_{m}=Q_{p} /(2 \pi v z) \text { and } R e_{r_{o}}=w r_{o}^{2} / v
$$

\subsubsection{Impingement Cooling}

In order to increase the heat removal and avoid overheating, it is possible to use impingement cooling at the disc rim. Disc cooling by impingement is usually done on the first turbine stage where the temperatures are higher. Typical cooling parameters can be used to obtain an order of magnitude for the convective heat transfer coefficient. Thus, it is possible to compare the temperature distribution obtained by impingement cooling and convection cooling. Then, the most appropriated method may be selected. The correlation proposed by Evans [18] is

$$
\begin{gathered}
\overline{N u}=\varnothing_{1} \varnothing_{2} \frac{K_{\theta}}{K_{90}} \operatorname{Re}_{D}^{m} \operatorname{Pr}^{1 / 3}\left(\frac{Z n}{D}\right)^{0.0091}, \\
\varnothing_{1}=3.48 /(X n / D)^{2.79}, \varnothing_{2}=1 /[1+0.459(\mathrm{Zn} / D)] \text { and } m=0.538(X n / D)^{0.237},
\end{gathered}
$$

where $N u$ is the average impingement jet average Nusselt number, $\varnothing_{1}, \varnothing_{2}$, and $m$ are correlation coefficients, $K_{\theta} / K_{90}$ is the impingement angle coefficient, $R e_{D}$ is the impingement hole Reynolds number, $\operatorname{Pr}$ is the Prandtl number, $\mathrm{Zn}$ is the impingement hole to disc spacing, $\mathrm{Xn}$ is the circumferential spacing between holes, and $D$ is the hole diameter. Typical values are used to estimate the heat 
transfer coefficient: $X n / D=7.5, \mathrm{Zn} / \mathrm{D}=1.9, K_{\theta} / K_{90}=1$ (normal impingement), $R e_{D}=1 \times 10^{4}$ and $D=0.2(\mathrm{~mm})$. The average convection heat transfer coefficient is given by

$$
\bar{h}=\overline{N u} k / D \text {. }
$$

\subsubsection{Heat Transfer Coefficient without Cooling Flow}

The model of a spinning disc in an infinite medium is used for the rear turbine disc face, according to Evans [18]

$$
N u=0.0198\left(R e_{r_{o}}\right)^{0.8} \operatorname{Pr} \text { and } h=N u\left(k_{g} / r_{o}\right) .
$$

\subsection{Turbine Annular Passage: Inner and Outer Walls}

At the top of the disc, or disc platform, the Nusselt number may be estimated based on correlations of flow in a channel. The correlations of flow in a channel are also valid for the stators and diffuser inner and outer walls. The average Nusselt number is given by the correlation proposed by Evans [18]

$$
N u=\frac{h D_{p}}{k_{g}}=0.021\left(R e_{p}\right)^{0.8}(\operatorname{Pr})^{0.6}
$$

where $D_{p}$ is the hydraulic diameter of the blade to blade passage, $h$ is the average heat transfer coefficient, and $k_{g}$ is the conductivity of the combustion gases. The Reynolds number is given by the mass flow $G$ and by the hydraulic diameter

$$
R e_{p}=\left(D_{p} G\right) / \mu_{g} \text { and } D_{p}=\left(2 y_{m} S_{h u b}\right) /\left(y_{m}+S_{h u b}\right) .
$$

$y_{m}$ is the average blade height and $S_{h u b}$ is the blade pitch at disc platform. The mass flux $G=\rho V_{a v}$ is given by the gas density times the mean velocity vector computed as a function of the inlet $\beta_{1}$ and exit $\beta_{2}$ flow angles. Relative quantities are used when computing the properties of the discs

$$
V_{a v}=V a_{a v} /\left(\cos \beta_{a v}\right), V_{a v}=0.5\left(V a_{i}+V a_{e}\right) \text { and } \tan \beta_{a v}=0.5\left(\tan \beta_{2}-\tan \beta_{1}\right) .
$$

where $V a_{i}$ and $V a_{e}$ are the inlet and exit axial velocities. The heat transfer coefficient is given by

$$
h=k_{g} N u / D_{p} .
$$

At the disc annular passage outer surface, a similar approach could be used, but it would not take into account the leakage flow at the blade tip. Usually the heat transfer coefficient on this region is the same order of magnitude of the coefficient at blade tip. Therefore, at the disc annular passage outer surface, the same heat transfer coefficient at the blade tip presented in Section 2.2 is used.

\subsection{Heat Transfer on the Combustor Annular Passage}

The heat load to estimate the temperature distribution on the combustor is computed according to [19]. Radiation and convection from the combustion gases are in equilibrium with the radiation to the engine casing and convection to the air flow on the annular passage between combustor wall and casing. The radiation takes into account the combustion gases temperature and the gas emissivity. The convection on the annular passage inside the combustor and on the combustor/casing annular passage is computed according to the correlation [19]:

$$
\begin{gathered}
h_{a n}=0.02\left(\frac{k_{a i r} N u}{D_{a n}^{0.2}}\right)\left(\frac{\dot{m}_{a i r}}{A_{a n} \mu_{a i r}}\right)^{0.8}, \\
D_{a n}=2 H_{a n} \text { and } A_{a n}=\frac{\pi}{4}\left(D_{e x}^{2}-D_{i n}^{2}\right),
\end{gathered}
$$


where, $h_{a n}$ is the convection heat transfer coefficient, $k_{a i r}$ and $\mu_{\text {air }}$ are the conductivity and viscosity of the air, $D_{a n}$ is the hydraulic diameter of the annular passage, $\dot{m}_{a i r}$ is the air mass flow rate and $A_{a n}$ is the area of the annular passage. $D_{e x}$ and $D_{i n}$ are the external and internal annular passage diameters. $H_{a n}$ is the annulus height.

\section{Materials and Boundary Conditions}

The metallic alloys used to manufacture the single spool gas turbine are of paramount importance, since they will be subjected to high structural and thermal loads, and, consequently, they will be subjected to several failure modes. To illustrate, a few existing loads can be identified: centrifugal loads generated by rotational speed; tensile load due to thrust; pressure of gases that are compressed or expanded by discs blades or vanes, and, specially, high temperatures, which contribute to a reduction of the metallic alloys yield strengths and the appearance of high thermal stresses. Thus, very few metallic materials can be subjected to these conditions. Based on previous experience and acquired knowledge of other similar aeronautical gas turbine projects, the materials selected for the computational simulations are presented in Figures 3 and 4, whose composition are given in Table 1.

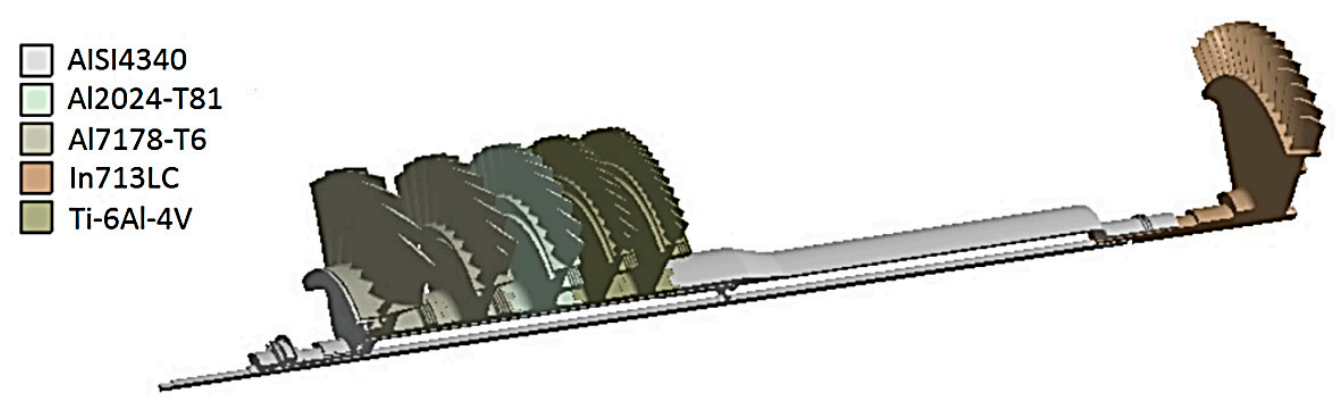

Figure 3. A one eighth section of the rotating assembly showing the chosen metallic alloys for each component.

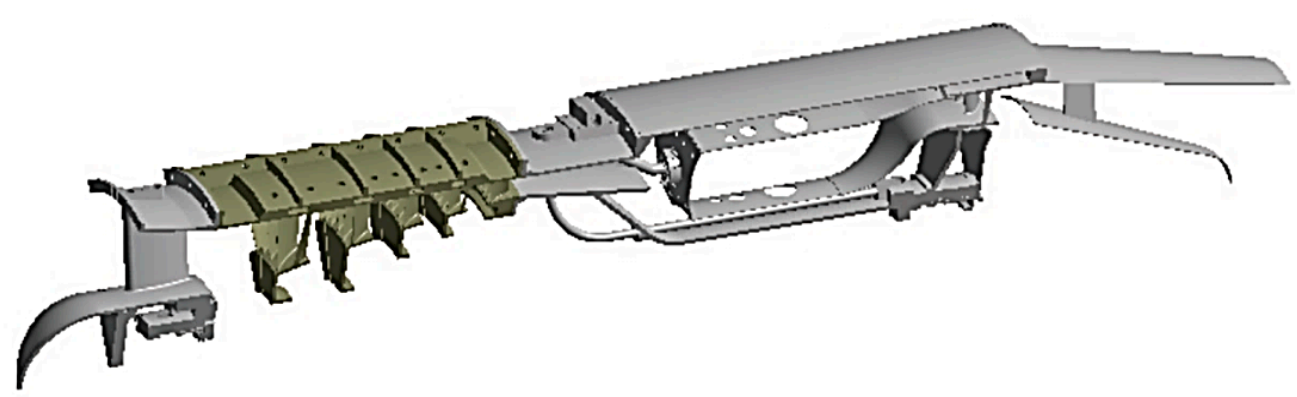

Figure 4. A one-eighth section of the static assembly showing the chosen metallic alloys for each component.

The values of the main mechanical properties of the metallic alloys used in the computational simulations of this work are presented in Table 2. Additional information about temperature and creep data can be found at MatWeb.com [20]. The boundary conditions were obtained from the mathematical modeling presented in Section 2. Figure 5 shows the compressor and turbine stages with respective working fluid pressure measurement points. Table 3 shows the respective numerical values of working fluid pressure at the compressor and turbine stages. All the heat transfer coefficients used in the computational simulations are presented in Table 4. 
Table 1. Compositions of the metallic alloys in terms of elements percentage.

\begin{tabular}{|c|c|}
\hline Metallic Alloys & Composition \\
\hline AISI4340 & $\begin{array}{c}\mathrm{C}(0.37-0.43 \%) ; \mathrm{Cr}(0.70-0.90 \%) ; \mathrm{Fe}(95.195-96.33 \%) \text { as remainder; } \\
\mathrm{Mn}(0.60-0.80 \%) ; \mathrm{Mo}(0.20-0.30 \%) ; \mathrm{Ni}(1.65-2.0 \%) ; \mathrm{P}(<=0.035 \%) \\
\text { Si }(0.15-0.30 \%) ; \mathrm{S}(<=0.040 \%)\end{array}$ \\
\hline Al2024-T81 & $\begin{array}{c}\mathrm{Al}(90.7-94.7 \%) \text { as remainder; } \mathrm{Cr}(<=0.10 \%) ; \mathrm{Cu}(3.8-4.9 \%) ; \\
\mathrm{Fe}(<=0.50 \%) ; \\
\mathrm{Mg}(1.2-1.8 \%) ; \mathrm{Mn}(0.30-0.90 \%) ; \mathrm{Si}(<=0.50 \%) ; \mathrm{Ti}(<=0.15 \%) ; \\
\mathrm{Zn}(<=0.25 \%)\end{array}$ \\
\hline Al7178-T6 & 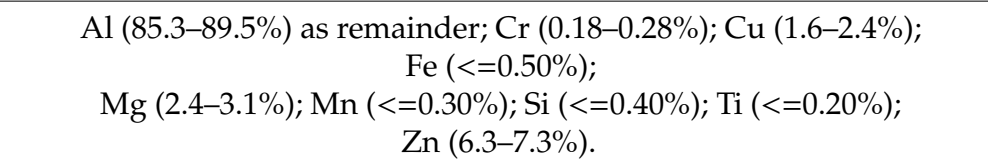 \\
\hline In713LC & $\begin{array}{c}\mathrm{Al}(6.1 \%) ; \mathrm{B}(1.012 \%) ; \mathrm{C}(0.12 \%) ; \mathrm{Cr}(12.5 \%) ; \mathrm{Ni}(77.368 \%) \text { as remainder; } \\
\mathrm{Nb} / \mathrm{Cb}(2.0 \%) ; \mathrm{Ti}(0.80 \%) ; \mathrm{Zr}(0.10 \%) .\end{array}$ \\
\hline Ti-6Al-4V & $\begin{array}{l}\mathrm{Al}(5.5-6.75 \%) ; \mathrm{C}(<=0.080 \%) ; \mathrm{H}(<=0.015 \%) ; \mathrm{Fe}(<=0.40 \%) ; \\
\mathrm{N}(<=0.030 \%) ; \\
\mathrm{O}(<=0.20 \%) ; \mathrm{Ti}(87.725-91 \%) \text { as remainder; } \mathrm{V}(3.5-4.5 \%)\end{array}$ \\
\hline
\end{tabular}

Table 2. Basic properties at room temperature of the high-performance metallic alloys used.

\begin{tabular}{|c|c|c|c|c|c|}
\hline Property & AISI4340 & Al2024-T81 & Al7178-T6 & In713LC & TI-6Al-4V \\
\hline Young modulus & $205 \mathrm{GPa}$ & $72.4 \mathrm{GPa}$ & $71.7 \mathrm{GPa}$ & $190 \mathrm{GPa}$ & $113.8 \mathrm{GPa}$ \\
\hline Density & $7850 \mathrm{~kg} / \mathrm{m}^{3}$ & $2780 \mathrm{~kg} / \mathrm{m}^{3}$ & $2830 \mathrm{~kg} / \mathrm{m}^{3}$ & $8000 \mathrm{~kg} / \mathrm{m}^{3}$ & $4430 \mathrm{~kg} / \mathrm{m}^{3}$ \\
\hline Yield strength & $862 \mathrm{MPa}$ & $450 \mathrm{MPa}$ & $540 \mathrm{MPa}$ & $750 \mathrm{MPa}$ & $873 \mathrm{MPa}$ \\
\hline Poisson's ratio & 0.29 & 0.33 & 0.33 & 0.382 & 0.342 \\
\hline Fatigue strength & $\begin{array}{l}150 \mathrm{MPa} \\
\left(1 \times 10^{6}\right)\end{array}$ & $\begin{array}{l}125 \mathrm{MPa} \\
\left(5 \times 10^{8}\right)\end{array}$ & $\begin{array}{l}150 \mathrm{MPa} \\
\left(5 \times 10^{8}\right)\end{array}$ & $\begin{array}{l}150 \mathrm{MPa} \\
\left(1 \times 10^{9}\right)\end{array}$ & $\begin{array}{l}150 \mathrm{MPa} \\
\left(5 \times 10^{8}\right)\end{array}$ \\
\hline Thermal conductivity & $44.5 \mathrm{~W} /(\mathrm{m} . \mathrm{K})$ & $151 \mathrm{~W} /(\mathrm{m} . \mathrm{K})$ & $125 \mathrm{~W} /(\mathrm{m} . \mathrm{K})$ & $21.6 \mathrm{~W} /(\mathrm{m} . \mathrm{K})$ & $6.7 \mathrm{~W} /(\mathrm{m} . \mathrm{K})$ \\
\hline Specific heat & $475 \mathrm{~J} /(\mathrm{kg} . \mathrm{K})$ & 875 J/ (kg.K) & $856 \mathrm{~J} /(\mathrm{kg} . \mathrm{K})$ & 648 J/ (kg.K) & $526.3 \mathrm{~J} /(\mathrm{kg} . \mathrm{K})$ \\
\hline $\begin{array}{c}\text { Thermal expansion } \\
\text { coefficient }\end{array}$ & $13.7 \mu \mathrm{m} /(\mathrm{m} . \mathrm{K})$ & $23.2 \mu \mathrm{m} /(\mathrm{m} . \mathrm{K})$ & $23.4 \mu \mathrm{m} /(\mathrm{m} . \mathrm{K})$ & $10 \mu \mathrm{m} /(\mathrm{m} . \mathrm{K})$ & $12.4 \mu \mathrm{m} /(\mathrm{m} . \mathrm{K})$ \\
\hline
\end{tabular}

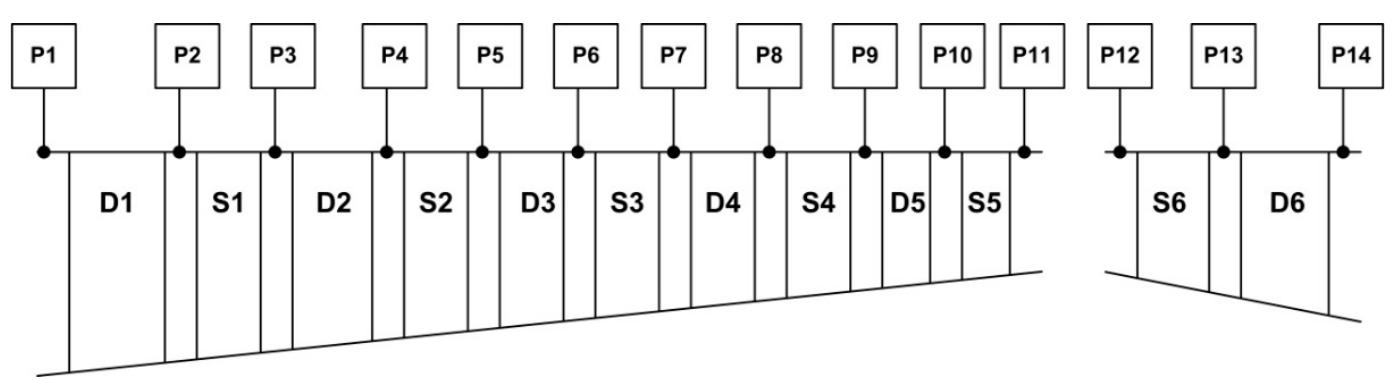

Figure 5. Working fluid pressures in measurement points at the compressor and turbine stages.

Table 3. Numerical values of working fluid pressures at the compressor and turbine stages.

\begin{tabular}{cccccc}
\hline & Total Pressure (Pa) & Static Pressure (Pa) & & Total Pressure (Pa) & Static Pressure (Pa) \\
\hline P1 & $101,325.0$ & $85,810.4$ & P8 & $494,712.9$ & $415,134.8$ \\
P2 & $159,589.4$ & $131,760.6$ & P9 & $474,924.4$ & $444,226.1$ \\
P3 & $153,205.8$ & $132,186.7$ & P10 & $633,281.3$ & $556,937.3$ \\
P4 & $243,236.0$ & $185,535.1$ & P11 & $607,950.0$ & $580,379.0$ \\
P5 & $233,506.6$ & $208,730.9$ & P12 & $476,227.5$ & $442,810.9$ \\
P6 & $357,671.4$ & $286,118.7$ & P13 & $460,006.8$ & $265,130.2$ \\
P7 & $343,364.6$ & $315,009.4$ & P14 & $223,318.8$ & $171,831.4$ \\
\hline
\end{tabular}


Table 4. Heat transfer coefficients used in the computational simulations.

\begin{tabular}{|c|c|c|c|c|c|}
\hline Local & $\begin{array}{c}\text { Convective Coefficient } \\
\left(\mathrm{W} /\left(\mathrm{m}^{2}{ }^{\circ} \mathrm{C}\right)\right)\end{array}$ & Temperature ${ }^{\circ} \mathrm{C}$ & Local & $\begin{array}{c}\text { Convective Coefficient } \\
\left(\mathrm{W} /\left(\mathrm{m}^{2}{ }^{\circ} \mathrm{C}\right)\right)\end{array}$ & Temperature $\left({ }^{\circ} \mathrm{C}\right)$ \\
\hline Turbine blade convex surface & 1265 & 706 & Compressor stator 4 blade surface & 2297 & 162 \\
\hline Turbine blade concave surface & 975 & 706 & Compressor stator 4 blade platform & 837 & 162 \\
\hline Turbine blade tip surface & 840 & 711 & Compressor stator 4 frontal surface & 744 & 154 \\
\hline Turbine blade platform & 839 & 699 & Compressor stator 4 back surface & 1111 & 169 \\
\hline Turbine disc frontal surface & 397 & 295 & Compressor stator 5 blade surface & 2561 & 206 \\
\hline Turbine disc back surface & 794 & 541 & Compressor stator 5 blade platform & 909 & 206 \\
\hline Compressor disc 1 blade surface & 1302 & 16 & Compressor stator 5 frontal surface & 933 & 200 \\
\hline Compressor disc 1 blade platform & 375 & 16 & Compressor top surface 1 st of 13 & 349 & 16 \\
\hline Compressor disc 1 blade tip surface & 349 & 16 & Compressor top surface 2 nd of 13 & 370 & 23 \\
\hline Compressor disc 1 frontal surface & 319 & 15 & Compressor top surface 3 rd of 13 & 417 & 37 \\
\hline Compressor disc 1 back surface & 407 & 44 & Compressor top surface 4 th of 13 & 443 & 44 \\
\hline Compressor disc 2 blade surface & 1461 & 45 & Compressor top surface 5 th of 13 & 480 & 55 \\
\hline Compressor disc 2 blade platform & 464 & 45 & Compressor top surface 6 th of 13 & 538 & 77 \\
\hline Compressor disc 2 blade tip surface & 443 & 45 & Compressor top surface 7 th of 13 & 558 & 88 \\
\hline Compressor disc 2 frontal surface & 428 & 44 & Compressor top surface 8th of 13 & 608 & 100 \\
\hline Compressor disc 2 back surface & 560 & 84 & Compressor top surface 9 th of 13 & 682 & 125 \\
\hline Compressor disc 3 blade surface & 1879 & 89 & Compressor top surface 10 th of 13 & 705 & 137 \\
\hline Compressor disc 3 blade platform & 575 & 89 & Compressor top surface 11 th of 13 & 762 & 150 \\
\hline Compressor disc 3 blade tip surface & 558 & 89 & Compressor top surface 12 th of 13 & 820 & 173 \\
\hline Compressor disc 3 frontal surface & 568 & 84 & Compressor top surface 13th of 13 & 889 & 205 \\
\hline Compressor disc 3 back surface & 742 & 131 & Cover surface around compressor & 50 & 20 \\
\hline Compressor disc 4 blade surface & 2575 & 137 & Rear bearing seal & 300 & 130 \\
\hline
\end{tabular}


Table 4. Cont

\begin{tabular}{|c|c|c|c|c|c|}
\hline Local & $\begin{array}{c}\text { Convective Coefficient } \\
\left(\mathrm{W} /\left(\mathrm{m}^{2}{ }^{\circ} \mathrm{C}\right)\right)\end{array}$ & Temperature ${ }^{\circ} \mathrm{C}$ & Local & $\begin{array}{c}\text { Convective Coefficient } \\
\left(\mathrm{W} /\left(\mathrm{m}^{2}{ }^{\circ} \mathrm{C}\right)\right)\end{array}$ & Temperature $\left({ }^{\circ} \mathrm{C}\right)$ \\
\hline Compressor disc 4 blade platform & 723 & 137 & Front bearing seal & 650 & 45 \\
\hline Compressor disc 4 blade tip surface & 705 & 137 & Front bearing stop & 450 & 40 \\
\hline Compressor disc 4 frontal surface & 744 & 131 & Spring of front bearing & 500 & 25 \\
\hline Compressor disc 4 back surface & 944 & 179 & Surface with oil at rear bearing & 2850 & 95 \\
\hline Compressor disc 5 blade surface & 3410 & 185 & Oil duct near front bearing & 1200 & 100 \\
\hline Compressor disc 5 blade platform & 841 & 185 & Aerofoil and oil duct & 2561 & 206 \\
\hline Compressor disc 5 blade tip surface & 823 & 185 & Static rear part of oil duct & 200 & 206 \\
\hline Compressor disc 5 frontal surface & 933 & 179 & Front bearing oil duct & 1200 & 70 \\
\hline Compressor disc 5 back surface & 1111 & 218 & Frontal thermal shield & 300 & 300 \\
\hline Turbine stator blade surface & 1250 & 830 & Back thermal shield & 400 & 310 \\
\hline Turbine stator blade platform & 850 & 830 & Outlet exhaustion duct & 50 & 20 \\
\hline Turbine stator top surface high & 1250 & 830 & Exhaustion duct top surface & 820 & 650 \\
\hline Turbine stator top surface low & 100 & 300 & Exhaustion duct inferior surface & 820 & 650 \\
\hline Turbine stator frontal surface & 500 & 350 & Exhaustion duct support & 1000 & 650 \\
\hline Turbine stator back surface & 300 & 300 & Exhaustion duct inner surface & 200 & 541 \\
\hline Compressor stator 1 blade surface & 1077 & 30 & Combustion chamber surface 1st of 6 & 560 & 1700 \\
\hline Compressor stator 1 blade platform & 415 & 30 & Combustion chamber surface 2 nd of 6 & 560 & 1200 \\
\hline Compressor stator 1 frontal surface & 319 & 30 & Combustion chamber surface 3rd of 6 & 560 & 900 \\
\hline Compressor stator 1 back surface & 560 & 30 & Combustion chamber surface 4 th of 6 & 920 & 300 \\
\hline Compressor stator 2 blade surface & 1439 & 65 & Combustion chamber surface 5 th of 6 & 400 & 300 \\
\hline Compressor stator 2 blade platform & 539 & 65 & Combustion chamber surface 6 th of 6 & 600 & 300 \\
\hline Compressor stator 2 frontal surface & 429 & 58 & Combustion chamber inner top & 900 & 300 \\
\hline Compressor stator 2 back surface & 742 & 72 & Cover around combustion chamber & 50 & 20 \\
\hline
\end{tabular}


Table 4. Cont.

\begin{tabular}{|c|c|c|c|c|c|}
\hline Local & $\begin{array}{c}\text { Convective Coefficient } \\
\left(\mathrm{W} /\left(\mathrm{m}^{2}{ }^{\circ} \mathrm{C}\right)\right)\end{array}$ & Temperature ${ }^{\circ} \mathrm{C}$ & Local & $\begin{array}{c}\text { Convective Coefficient } \\
\left(\mathrm{W} /\left(\mathrm{m}^{2}{ }^{\circ} \mathrm{C}\right)\right)\end{array}$ & Temperature $\left({ }^{\circ} \mathrm{C}\right)$ \\
\hline Compressor stator 3 blade surface & 1795 & 112 & Shaft end at rear bearing & 250 & 300 \\
\hline Compressor stator 3 blade platform & 676 & 112 & Shaft exterior surface & 400 & 300 \\
\hline Compressor stator 3 frontal surface & 568 & 104 & Shaft interior surface & 400 & 260 \\
\hline Compressor stator 3 back surface & 944 & 120 & Static rear part inner shaft & 900 & 300 \\
\hline Static interior back part & 150 & 250 & Static front part inner shaft & 400 & 300 \\
\hline Static interior platform part & 200 & 206 & Swiler & 500 & 250 \\
\hline \multicolumn{2}{|l|}{ Local } & \multicolumn{2}{|c|}{ Emissivity/Radiation } & \multicolumn{2}{|c|}{ Temperature $\left({ }^{\circ} \mathrm{C}\right)$} \\
\hline \multicolumn{2}{|c|}{ Combustion chamber interior high } & \multicolumn{2}{|r|}{0.6} & \multicolumn{2}{|c|}{1700} \\
\hline \multicolumn{2}{|c|}{ Combustion chamber interior medium } & \multicolumn{2}{|r|}{0.6} & \multicolumn{2}{|c|}{1200} \\
\hline \multicolumn{2}{|c|}{ Combustion chamber interior low } & \multicolumn{2}{|r|}{0.6} & \multicolumn{2}{|c|}{900} \\
\hline \multicolumn{2}{|c|}{ Static part around combustion chamber } & \multicolumn{2}{|r|}{0.6} & \multicolumn{2}{|c|}{980} \\
\hline \multicolumn{2}{|c|}{ Static part below combustion chamber } & \multicolumn{2}{|r|}{0.6} & \multicolumn{2}{|c|}{1100} \\
\hline \multicolumn{2}{|c|}{ Static part around turbine disc } & \multicolumn{2}{|r|}{0.6} & \multicolumn{2}{|c|}{600} \\
\hline
\end{tabular}




\section{Results and Discussion}

Due to the radial symmetry of the engine, a one eighth section of the turbine was chosen for the model. The rotating and static components were analyzed independently. The turbine heat transfer analysis was performed using the heat transfer coefficients and the finite element method with the software Ansys. The geometries were modelled with hexadominant meshes composed mainly of hexahedral elements and their respective variations. All these elements have shown to provide sufficiently good results in heat transfer problems. In Ansys, a hexadominant solid mesh is formed with Solid186 elements. Solid186 is a higher order 3D 20-node solid element that exhibits quadratic displacement behavior. The element is defined by 20 nodes having 3 degrees of freedom per node: translations in the nodal $x, y$, and $z$ directions. The element supports plasticity, hyperelasticity, creep, stress stiffening, large deflection, and large strain capabilities. It also has mixed formulation capability for simulating deformations of nearly incompressible elastoplastic materials, and fully incompressible hyperelastic materials. The geometry, node locations, and the element coordinate system for this element are shown in Figure 6. A prism-shaped element may be formed by defining the same node numbers for nodes K, L, and S; nodes A and B; and nodes O, P, and W. Similarly, pyramidal- and tetrahedral-shaped elements may also be formed as shown. Their respective shape functions and integration points can be found in [21,22].
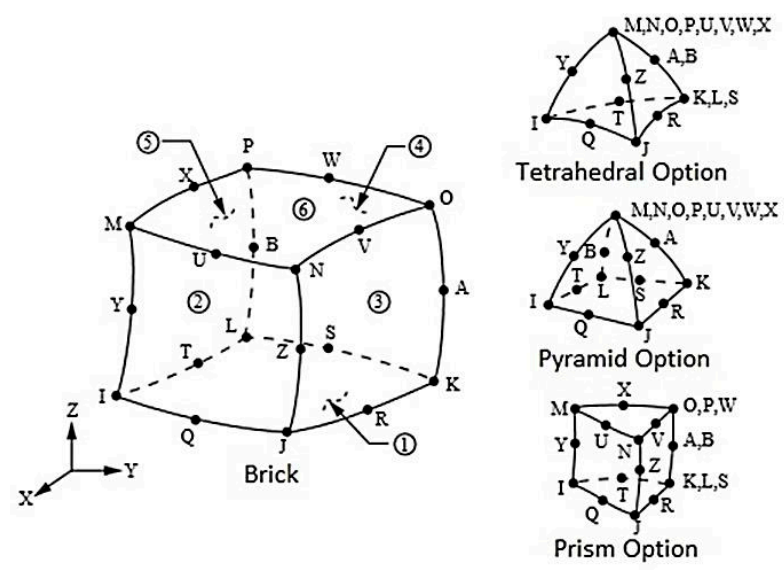

Figure 6. Solid186 element in Ansys and its variations according to [23].

\subsection{Temperature Distribution over the Rotating Assembly}

Figure 7 shows the temperature distribution of the rotating assembly calculated by the finite element method. The boundary conditions were specified using the heat transfer coefficients calculated by the correlations presented previously.
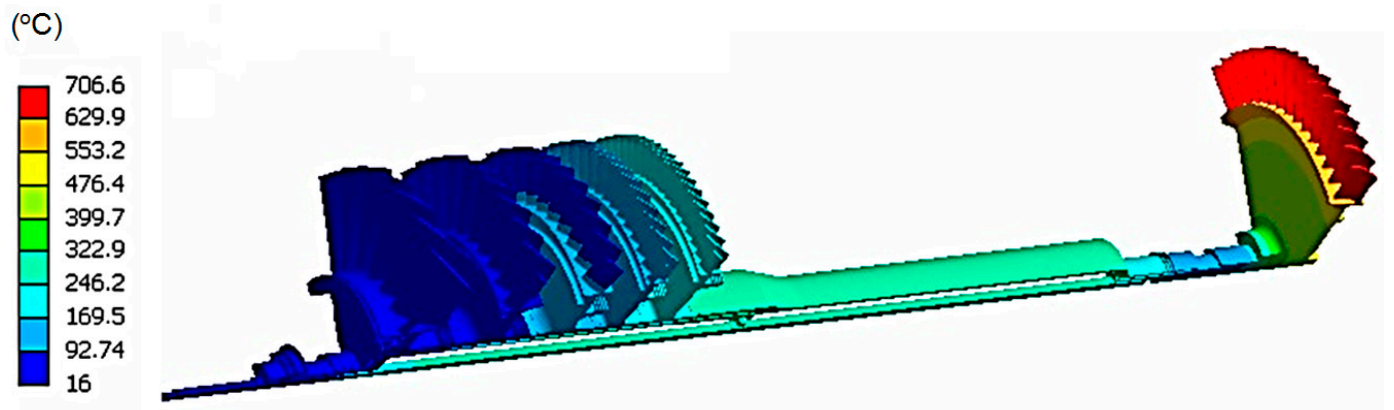

Figure 7. Temperature distribution over a one eighth section of the rotating assembly.

Part of the air which leaves the compressor is used to seal the front bearing in order to prevent oil leakage. This air stream passes near the combustion chamber and gets into the interior of the shaft. 
From the interior of the shaft, the air is directed to the front bearing to accomplish its function of sealing. However, when the air passes near the region of the combustion chamber, it suffers a considerable temperature increase. At the compressor exit, the air temperature is about $210^{\circ} \mathrm{C}$ and due to the heat transfers along the way, the air temperature reaches approximately $280^{\circ} \mathrm{C}$. This fact justifies the temperature over the interior of the shaft being higher than the temperature of the last compressor disc. This can be seen in Figure 8a. It is also interesting to note the temperature gradient on the interior surface of the shaft just below the compressor disc, Figure 8b. This temperature gradient is explained by the fact that the second, third and fourth discs do not touch the exterior surface of the shaft. Thus, at this location, the shaft does not lose heat by conduction through these rotors and an increase in temperature can be clearly observed in this region.

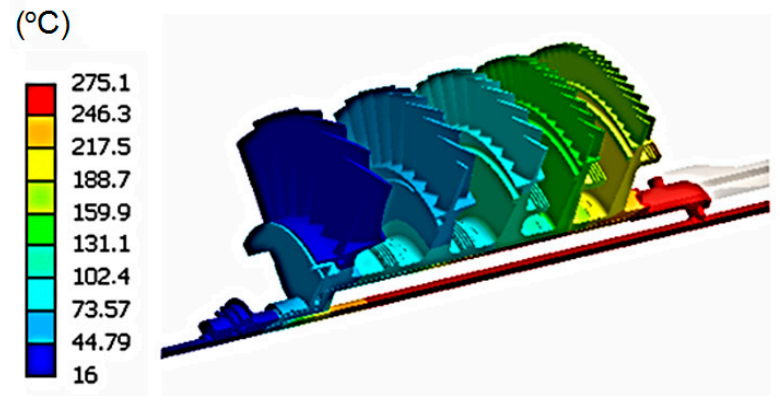

(a)

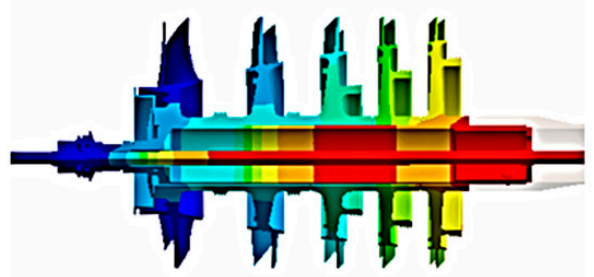

(b)

Figure 8. Temperature distribution over the compressor disc and shaft: (a) Perspective view; (b) Inner shaft view.

It is important to evaluate the temperature at certain points. Figure 9a emphasizes the temperature on the inner rear bearing ring surface, which can reach $114{ }^{\circ} \mathrm{C}$. Figure $9 \mathrm{~b}$ shows the difference in temperature from the front disc face to the rear disc face. The difference in temperature can reach $100^{\circ} \mathrm{C}$, which causes a distortion in the turbine disc geometry. This difference in temperature is due to the fact that the rear disc face is uncooled. Figure $9 \mathrm{c}$ shows the temperature distribution over a single turbine blade, being almost radial, as expected for an uncooled turbine blade.

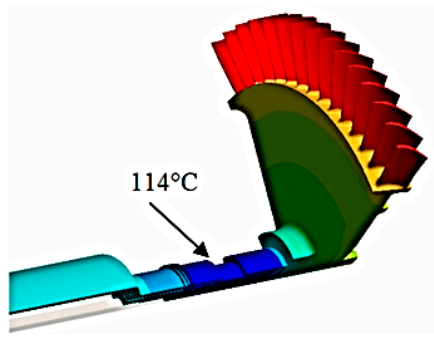

(a)

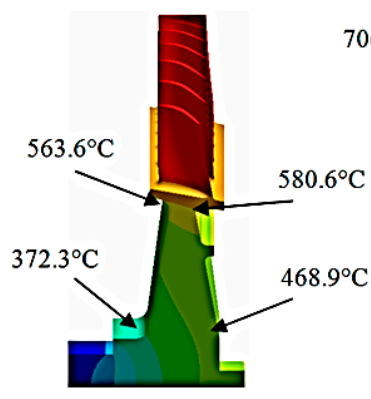

(b)

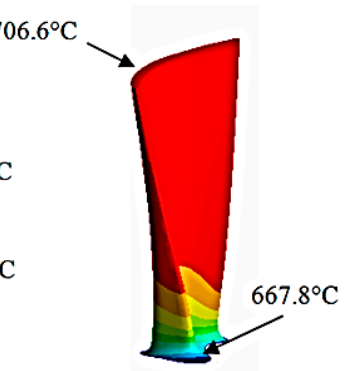

(c)

Figure 9. (a) Temperature distribution over the turbine disc; (b) temperature distribution along the disc profile; (c) temperature distribution over a single turbine blade.

\subsection{Temperature Distribution over the Static Assembly}

Figure 10 shows the temperature distribution of the static assembly. In this analysis, it is very important to take into account the heat transfer by radiation, especially in those components near the combustion chamber. Figure 11 shows the temperature field over the compressor stator vanes. Higher temperatures are found on the last stages as expected. 
$\left({ }^{\circ} \mathrm{C}\right)$

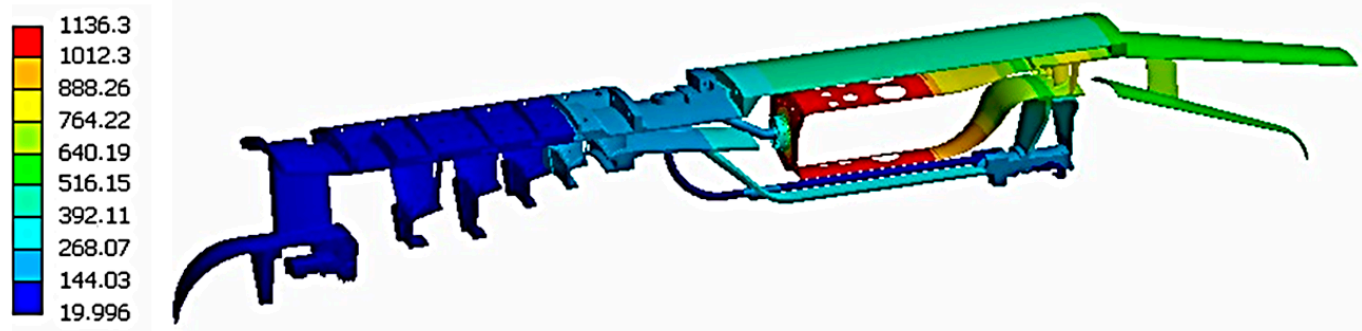

Figure 10. Temperature distribution over one eighth section of the static assembly.

$\left({ }^{\circ} \mathrm{C}\right)$
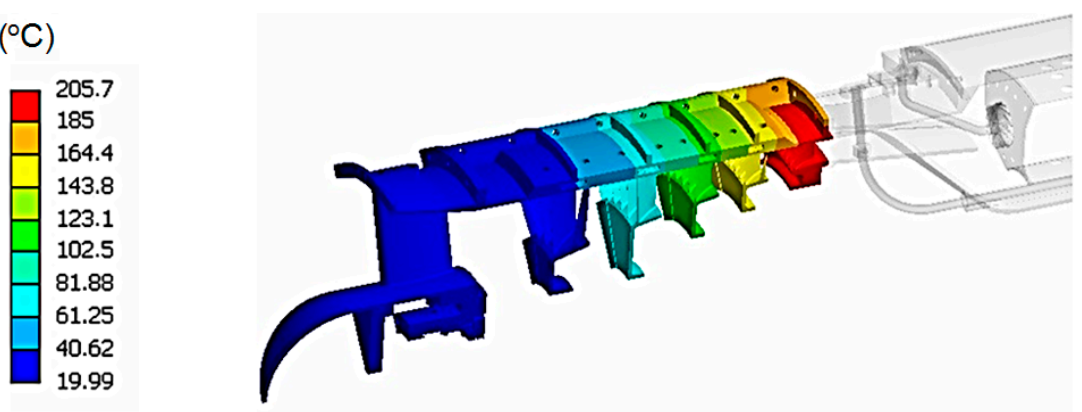

Figure 11. Temperature distribution over the compressor stator vanes.

The temperature distribution over the static components near the combustion chamber is shown in Figure 12. The lowest temperature is $89.4{ }^{\circ} \mathrm{C}$ and is located in the beginning of the feeding oil tube. Along this tube, thermal insulation is required to prevent oil overheating. The oil in this tube is responsible for refrigeration, lubrication, and reduction of vibration in the rear bearing since it is a squeeze film damper. The estimated temperature over the outer bearing ring is $141.4{ }^{\circ} \mathrm{C}$. This temperature is calculated considering that the oil is at $95^{\circ} \mathrm{C}$ in the rear bearing, limited by the oil cooling system.
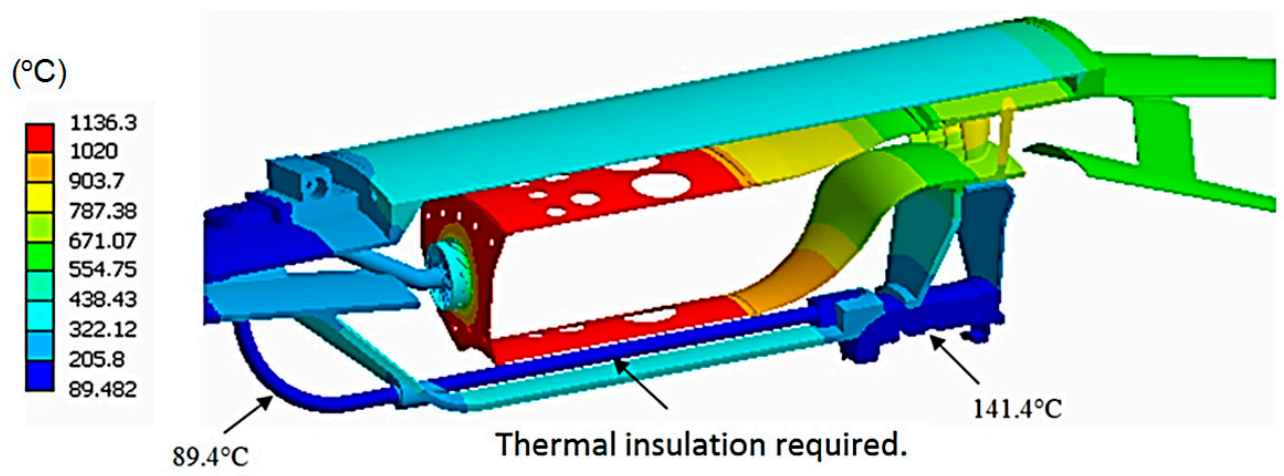

Figure 12. Temperature distribution near the combustion chamber.

\subsection{Thermal Expansion Behavior over the Rotating and Static Assemblies}

Figure 13 shows the thermal expansion behavior along the rotating assembly. The displacement at the inner rear bearing ring surface is $1.656 \mathrm{~mm}$. Figure 14 shows the thermal expansion behavior along the static assembly. The calculated displacement at the outer rear bearing ring surface is $1.891 \mathrm{~mm}$. These analyses were performed by considering the design point conditions at maximum rotational speed. The rear bearing is a critical component regarding the thermal expansion effects. The thermal expansion variation between the rotating and static assemblies indicates that the rear bearing slides $0.235 \mathrm{~mm}$ towards the front bearing. The prediction of this movement allows the appropriate rolling bearing specification and its correct position in the whole bearing assembly. 
(m)

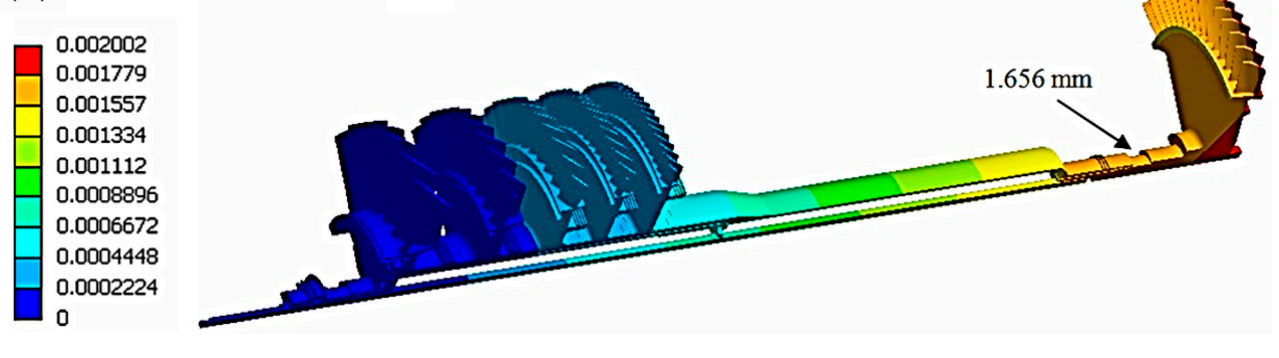

Figure 13. Thermal expansion along the rotating assembly.

(m)

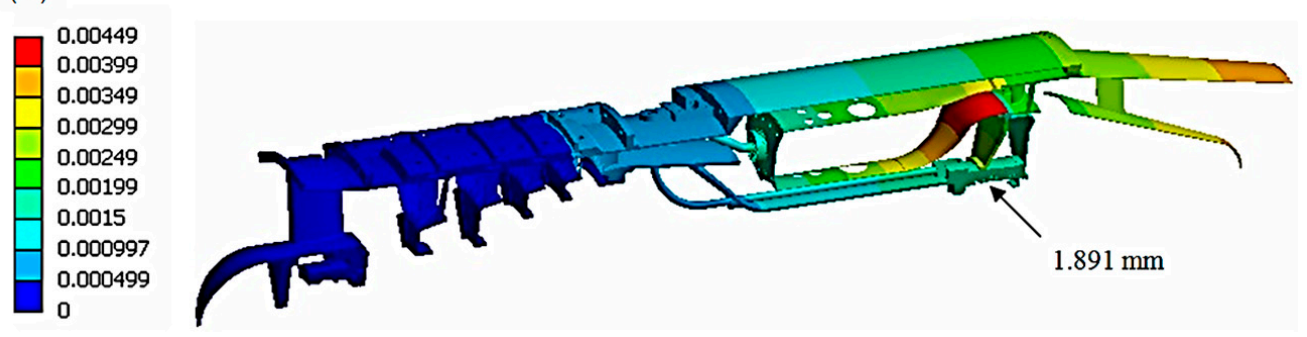

Figure 14. Thermal expansion along the static assembly.

Figure 15a shows the clearance in the coupling of the combustion chamber outer wall with the turbine stator at room temperature. The effect caused by thermal expansion at the design point conditions can be seen in Figure 15b. At room temperature the clearance measures $3.21 \mathrm{~mm}$. After thermal expansion, the clearance reduces to $1.2 \mathrm{~mm}$.

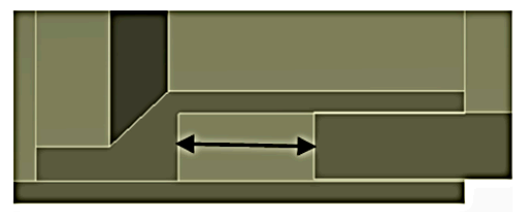

(a)

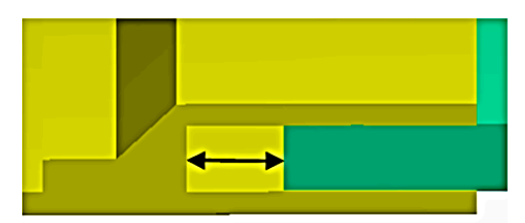

(b)

Figure 15. Coupling of the combustion chamber outer wall with the turbine stator: (a) Position at room temperature; (b) new position after thermal expansion.

The lower part of the combustion chamber is simply supported by the turbine stator. The combustion chamber can slide, due to thermal expansion, over the turbine stator. Figure 16a shows the assembly position at room temperature. Figure $16 \mathrm{~b}$ shows the new position after thermal expansion. After thermal expansion, the lower part of the combustion chamber slides $2.526 \mathrm{~mm}$ towards the turbine stator vanes, but no potential problem was observed.

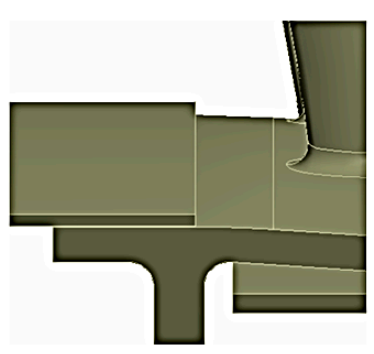

(a)

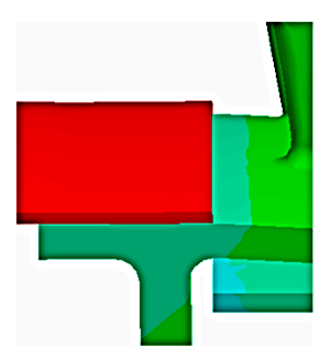

(b)

Figure 16. Coupling of the combustion chamber inner wall with the turbine stator. (a) Position at room temperature; (b) new position after thermal expansion. 
It is also important to evaluate the clearances between the turbine rotor and the static components. Figure 17 shows the dimensions D1 and D2 evaluated at room temperature and after the thermal expansion using the design point conditions at the maximum rotational speed. D1 represents the clearance between the turbine disc and the turbine stator, and D2 represents the clearance between the turbine disc and the exhaustion duct. Dimension D1 measures $4.296 \mathrm{~mm}$ at room temperature and it has a reduction of $0.761 \mathrm{~mm}$ after thermal expansion. In the same way, dimension D2 measures $3.067 \mathrm{~mm}$ at room temperature and it has a reduction of $0.494 \mathrm{~mm}$ after thermal expansion.

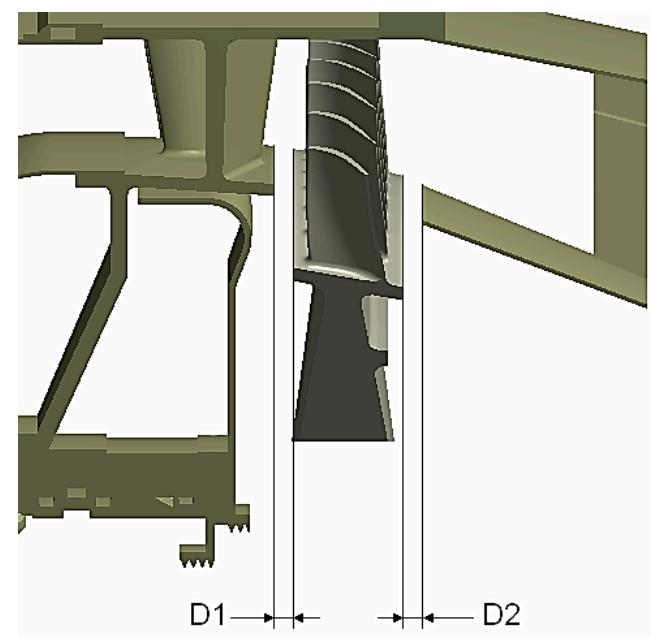

Figure 17. Illustration of the clearances between the turbine disc and the static components.

\section{Conclusions}

A heat transfer analysis in a one eighth section of a single spool gas turbine has been successfully performed. The temperature distribution over the complete aeronautical gas turbine, including the rotating and static assemblies, have been estimated using the heat transfer correlations and the finite element method. The highest temperatures were found on the turbine blades considering the rotating components, and on the combustion chamber considering the static components. Film cooling is recommended on the combustion chamber due to the temperature peaks of $1136^{\circ} \mathrm{C}$. The temperature on the rear bearing is consistent with commercial rolling bearings operation limits. The oil tube must be insulated to avoid oil and bearing overheating. The thermal expansion behavior of the clearances was also evaluated. The gaps between the rotating and static components suffer a reduction after thermal expansion, but no overlapping or potential problem was found. It was observed that the rear bearing slides $0.235 \mathrm{~mm}$ towards the front bearing. The prediction of this movement allows an appropriate rolling bearing specification and the determination of its correct position along the whole bearing assembly. The thermal expansion behavior predicted on the one eighth section of the studied single spool gas turbine is consistent with acceptable practical values. Thus, the mechanical drawings can be released to manufacturing.

Author Contributions: Investigation, G.C. and M.T.d.M.; Formal analysis, G.C. and M.T.d.M.; Resources, J.C.M. and J.R.B.; Supervision, J.C.M. and J.R.B.; Project administration, J.R.B. All authors have read and agreed to the published version of the manuscript.

Funding: This research received no external funding.

Acknowledgments: All authors thank the support received and acknowledged in [1-3]. The first author would also like to thank CAPES and CNPq 385582/2006-4 for their financial support.

Conflicts of Interest: The authors declare no conflict of interest. 


\section{References}

1. Creci, G.; Menezes, J.C.; Barbosa, J.R.; Corra, J.A. Rotordynamic Analysis of a 5-Kilonewton Thrust Gas Turbine by Considering Bearing Dynamics. J. Propuls. Power 2011, 27, 330-336. [CrossRef]

2. Creci Filho, G. Influência da Dinâmica dos Mancais na Resposta Vibratória de uma Turbina Aeronáutica de 5kN de Empuxo. Ph.D. Thesis, Instituto Tecnológico de Aeronáutica, São José dos Campos, Brazil, 2012; p. 307. Available online: http://www.bdita.bibl.ita.br/tesesdigitais/lista_resumo.php?num_tese=62130 (accessed on 20 November 2020).

3. Creci, G.; Balastrero, J.O.; Domingues, S.; Torres, L.V.; Menezes, J.C. Influence of the Radial Clearance of a Squeeze Film Damper on the Vibratory Behavior of a Single Spool Gas Turbine Designed for Unmanned Aerial Vehicle Applications. Shock. Vib. 2017, 2017, 4312943. [CrossRef]

4. Leme, A.D.S.; Creci, G.; De Jesus, E.R.B.; Rodrigues, T.C.; Menezes, J.C. Finite Element Analysis to Verify the Structural Integrity of an Aeronautical Gas Turbine Disc Made from Inconel 713LC Superalloy. Adv. Eng. Forum 2019, 32, 15-26. [CrossRef]

5. Mazur, Z.; Luna-Ramírez, A.; Juárez-Islas, J.; Campos-Amezcua, A. Failure analysis of a gas turbine blade made of Inconel 738LC alloy. Eng. Fail. Anal. 2005, 12, 474-486. [CrossRef]

6. Sadowski, T.; Golewski, P. Multidisciplinary analysis of the operational temperature increase of turbine blades in combustion engines by application of the ceramic thermal barrier coatings (TBC). Comput. Mater. Sci. 2011, 50, 1326-1335. [CrossRef]

7. Kim, K.M.; Park, J.S.; Lee, D.H.; Lee, T.W.; Cho, H.H. Analysis of conjugated heat transfer, stress and failure in a gas turbine blade with circular cooling passages. Eng. Fail. Anal. 2011, 18, 1212-1222. [CrossRef]

8. El-Batsh, H.M.; Nada, S.A.; Abdo, S.N.; El-Tayesh, A.A. Effect of Secondary Flows on Heat Transfer of a Gas Turbine Blade. Int. J. Rotating Mach. 2013, 2013, 797841. Available online: https://www.hindawi.com/ journals/ijrm/2013/797841/ (accessed on 20 November 2020). [CrossRef]

9. Fu, C.-Z.; Si, W.; Quan, L.; Yang, J. Numerical Study of Convection and Radiation Heat Transfer in Pipe Cable. Math. Probl. Eng. 2018, 2018, 5475136. [CrossRef]

10. Bade, M.; Clark, N.N.; Robinson, M.C.; Famouri, P. Parametric Investigation of Combustion and Heat Transfer Characteristics of Oscillating Linear Engine Alternator. J. Combust. 2018, 2018, 2907572. [CrossRef]

11. Dou, H.-S.; Jiang, G.; Zhang, L.-T. A Numerical Study of Natural Convection Heat Transfer in Fin Ribbed Radiator. Math. Probl. Eng. 2015, 2015, 989260. [CrossRef]

12. Jedsadaratanachai, W.; Boonloi, A. Numerical Study on Turbulent Forced Convection and Heat Transfer Characteristic in a Circular Tube with V-Orifice. Model. Simul. Eng. 2017, 2017, 3816739. [CrossRef]

13. Badreddine, H.; Sato, Y.; Berger, M.; Ničeno, B. A Three-Dimensional, Immersed Boundary, Finite Volume Method for the Simulation of Incompressible Heat Transfer Flows around Complex Geometries. Int. J. Chem. Eng. 2017, 2017, 1726519. [CrossRef]

14. Devaraj, C.; Muthuswamy, E.; Kandasamy, S. Numerical Investigation of Laminar Natural Convection in Inclined Square Enclosure with the Influence of Discrete Heat Source. J. Appl. Math. 2015, 2015, 985218. [CrossRef]

15. Schlichting, H. Boundary Layer Theory, 6th ed.; McGraw-Hill: New York, NY, USA, 1968; Available online: https://books.google.com.br/books?id=6IZTAAAAMAAJ (accessed on 20 November 2020).

16. Colladay, R. Turbine Design and Application; NASA SP 290, Turbine Cooling; National Aeronautics and Space Administration, Lewis Research Center: Cleveland, OH, USA, 1975; Volume 3, pp. 59-101.

17. White, F.M. Viscous Fluid Flow; McGraw-Hill: New York, NY, USA, 1974; Available online: https://books. google.com.br/books?isbn=007124493X (accessed on 20 November 2020).

18. Evans, D.M. Calculation of Temperature Distribution in Multistage Axial Gas Turbine Rotor Assemblies When Blades Are Uncooled. J. Eng. Power 1973, 95, 309-318. [CrossRef]

19. Lefebvre, A.H. Gas Turbine Combustion, 2nd ed.; Taylor \& Francis Ltd.: Ann Arbor, MI, USA, 1999; Available online: https://books.google.com.br/books?isbn=1560326735 (accessed on 20 November 2020).

20. MATWEB: Material Property Data. 2018. Available online: http://www.matweb.com/ (accessed on 20 November 2020).

21. Zienkiewicz, O.C. The Finite Element Method; McGraw-Hill Company: London, UK, 1977; Available online: https://books.google.com/books?isbn=0070840725 (accessed on 20 November 2020). 
22. Moaveni, S. Finite Element Analysis: Theory and Application with Ansys; Prentice Hall: Upper Saddle River, NJ, USA, 1999; Available online: https://books.google.com/books?isbn=0137850980 (accessed on 20 November 2020).

23. Ansys®Academic Research Documentation Manual, Release 18.2, Help System, Guide. ANSYS, Inc. Available online: https://www.ansys.com/ (accessed on 20 November 2020).

Publisher's Note: MDPI stays neutral with regard to jurisdictional claims in published maps and institutional affiliations.

(C) 2020 by the authors. Licensee MDPI, Basel, Switzerland. This article is an open access article distributed under the terms and conditions of the Creative Commons Attribution (CC BY) license (http://creativecommons.org/licenses/by/4.0/). 